\title{
Forward Osmosis to Concentrate Lithium from Brine: The Effect of Operating Conditions ( $\mathrm{pH}$ and Temperature)
}

\author{
Sutijan ${ }^{1,2}$, Satrio Wahyudi ${ }^{1}$, Muhammad Fadlil Ismail ${ }^{1}$, Pra Cipta Buana Mustika ${ }^{1}$, \\ Widi Astuti ${ }^{3}$, Agus Prasetya ${ }^{1,2}$, Himawan Tri Bayu Murti Petrus ${ }^{1,2^{*}}$ \\ ${ }^{1}$ Department of Chemical Engineering (Sustainable Mineral Processing Research Group), Faculty of Engineering, \\ Universitas Gadjah Mada, Jalan Grafika No. 2 Kampus UGM Bulaksumur, D.I. Yogyakarta 55281, Indonesia \\ ${ }^{2}$ Unconventional Geo-resources Research Group, Faculty of Engineering, Universitas Gadjah Mada, Jalan Grafika \\ No. 2 Kampus UGM Bulaksumur, D.I. Yogyakarta 55281, Indonesia \\ ${ }^{3}$ Research Unit for Mineral Technology, National Research and Innovation Agency (BRIN), Jl. Ir. Sutami Km. 15, \\ Tanjung Bintang, Lampung Selatan, Lampung 35361, Indonesia
}

\begin{abstract}
The development of battery technology is the driving force behind the increasing demand for lithium, which has resulted in a decreased supply of lithium in the market and continues to be a challenge for the industry. In response to these conditions, the development of lithium recovery technology continues, and there is a search for sources of lithium that are easier to recover. One source of lithium that has the potential to be processed is geothermal brine using forward osmosis technology. The aim of this study was to determine the best operating conditions for forward osmosis as a substitute for conventional evaporation methods. The parameters to be optimized included $\mathrm{pH}$ and operating temperature. The flow rate in the forward osmosis process was controlled by two litres per hour ( $\mathrm{LPH})$, while the concentration of the draw solution was $6 \mathrm{M}$. The operating temperature variations used were $40^{\circ} \mathrm{C}, 35^{\circ} \mathrm{C}$, and $30^{\circ} \mathrm{C}$, while the $\mathrm{pH}$ variations used were 7,6 , and 5 . The best results were achieved at a $\mathrm{pH}$ of 5 with a temperature of $40^{\circ} \mathrm{C}$. Apart from these operating conditions, the activity model (the Pitzer equation) showed superior results compared to the simple model (the Van't Hoff equation), explaining the forward osmosis phenomenon.
\end{abstract}

Keywords: Battery; Forward osmosis; Geothermal brine; Lithium; Optimization

\section{Introduction}

Lithium is one of the crucial elements because of its role in various fields, especially energy, industry, pharmaceuticals, manufacturing, and the economic sector (Hamzaoui et al., 2003). In the energy sector, increased production and electric car technology developments are predicted to be the main drivers of the increased demand for lithium. The growth in electric car production is expected to require a major market share in lithium in the 21st century (Gruber et al., 2011; Li et al., 2018). Data show that up to this point, the highest lithium consumption is still dominated by the battery production sector, and this will continue to increase over time (Naumov and Naumova, 2010). The demand for lithium in 2015 reached 173,000 tons and continues to increase (Martin et al., 2017). 
Lithium on earth is found in more than 150 minerals, clay, continental brine, geothermal brine, and seawater. Hydrometallurgical lithium recovery from minerals and clays is economically less profitable than that from the brines and has the potential to cause pollution due to the use of large quantities of complex chemicals (Swain, 2017). Usually, the concentration of lithium in seawater is very low at around $0.17 \mathrm{ppm}$, while geothermal brine ranges from 0-100 ppm. Therefore, geothermal brine can be classified as a promising source of lithium availability to be commercialized economically and technically. Setiawan et al. researched lithium from geothermal brine in Indonesia. The research results show that geothermal brine from Dieng, Central Java contains lithium at an average of close to 40 ppm (Setiawan et al., 2019). Lithium recovery technology from geothermal brine is the most widely used method of evaporation (Flexer et al., 2018). However, this method tends to have many disadvantages, such as long processing times, a required area, and erratic processing energy. To deal with this problem, several methods have been developed for lithium recovery, one of which is forward osmosis.

The driving force behind forward osmosis comes from the difference in osmotic pressure between the feed and the draw solution, which results from the difference in concentration. (Cath et al., 2006). The forward osmosis process does not require high pressure like reverse osmosis (RO) (Utami et al., 2015; Desiriani et al., 2017; Suprapto et al., 2020) or a high temperature. As a result, the membrane's fouling rate is low, and the energy value and costs required for cleaning are low (Holloway et al., 2007; McGinnis and Elimelech, 2007). The recovery of lithium from geothermal brine is carried out by drawing a quantity of water from the feed fluid body across the membrane to the draw solution fluid body (Wang et al., 2014; Awad et al., 2019). The process of displacement occurs naturally and spontaneously until it reaches equilibrium. Meanwhile, the purpose of this research is to determine the best operating conditions for the forward osmosis process to concentrate lithium from geothermal brine-a process that is feasible to continue at the commercialization stage.

\section{Materials and Methods}

\subsection{Forward Osmosis Membranes}

The cellulose acetate (CTA)-based membrane used in this research was supplied by FTS $\mathrm{H}_{20} \mathrm{~T}^{\mathrm{Tm}}$. The membrane used has an active side and a support side so that an asymmetric system is formed. The membrane is arranged asymmetrically, with an active and supporting side (Kim et al., 2017). The membrane has an operating $\mathrm{pH}$ range from 2-7; the maximum operating temperature is $50^{\circ} \mathrm{C}$.

\subsection{Feed and Draw Solutions}

The feed solution was synthesized by dissolving a mass of lithium chloride ( $\mathrm{LiCl}$ ) into aquadest until a concentration of $25 \mathrm{ppm}$ was obtained. The stages of making a draw solution are also the same, namely, dissolving a mass of sodium chloride ( $\mathrm{NaCl}$ ) into the aquadest. The expected concentration is $6 \mathrm{M}$, given $\mathrm{NaCl}$ 's maximum solubility at $25^{\circ} \mathrm{C}, 357$ $\mathrm{g} / \mathrm{L}$. The properties of the solution required for the study were analyzed using the Aspen Plus simulation approach to provide the required thermodynamic properties approach.

\subsection{Forward Osmosis System}

Lab-scale forward osmosis cells supplied by Sterlitech with type CF042 were used in this study. The active membrane area in this cell is $42 \mathrm{~cm}^{2}\left(3.2 \mathrm{in}^{2}\right)$, and the maximum operating pressure is up to 400 psi (27.6 bar). Experimental parameter verification is performed by simulating the dynamics of the flow across the membrane in the forward osmosis system (Khraisheh et al., 2020). 


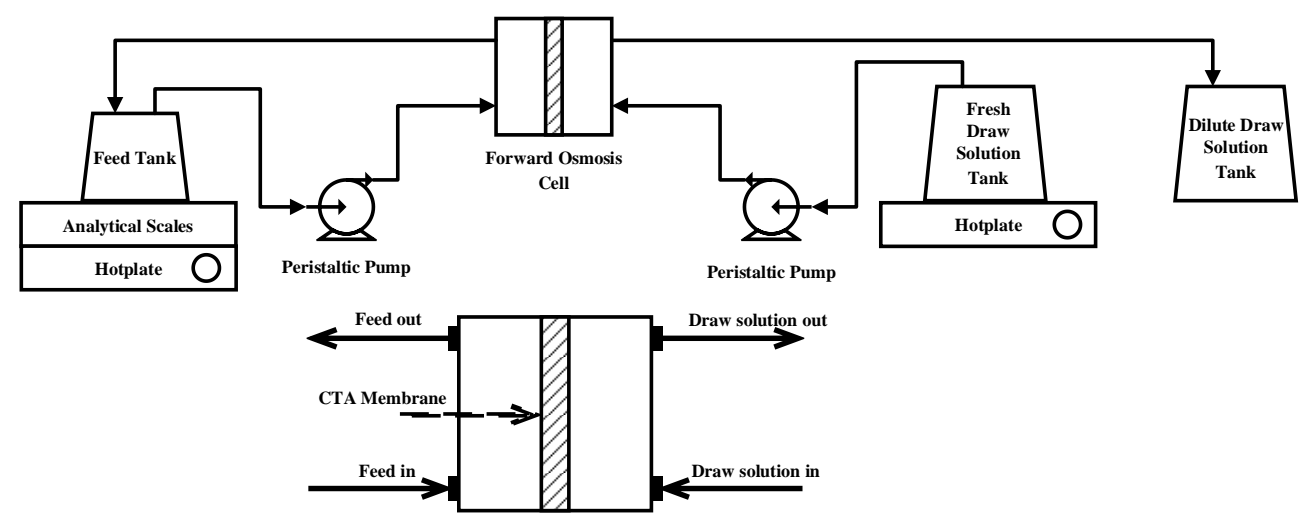

Figure 1 Experimental apparatus for a forward osmosis (FO) cell

The flow rate used in the forward osmosis system is set at a value of two LPH. The circulation process in the forward osmosis system is carried out by flowing cycles using two peristaltic pumps. A controlled heating system is required during the process, so a temperature-controlled hotplate is used. The forward osmosis process lasts for two hours, with data retrieval was carried out every five minutes by weighing the change in mass measured on a digital scale during the process. As much as $5 \mathrm{~mL}$ of the sample before and after the process was also taken. The samples were analyzed using AAS so that the lithium rejection could be calculated.

\section{Theoretical Modelling}

\subsection{Water Flux Modelling}

In the forward osmosis process, the driving force comes from the difference in osmotic pressure resulting from different concentrations on the feed and draw solution sides (Monjezi et al., 2017). As a result, water from the feed side is attracted to the draw solution side across the membrane. In general, this phenomenon produces water flux, which can be written in the following equation:

$$
\mathrm{J}_{\mathrm{W}}=\mathrm{A}\left(\pi_{\mathrm{D}}-\pi_{\mathrm{F}}\right)
$$

where $A$ is the water permeability coefficient on the membrane, $\pi_{D}$ is the osmotic pressure of the draw solution, and $\pi_{\mathrm{F}}$ is the osmotic pressure of the feed. The water flux model in Equation 1 does not accommodate the effect of concentration polarization due to differences in osmotic pressure. When the feed faces the active site of the membrane while the draw solution is on the support side, the feed passes through the membrane's pores, and a higher concentration is formed, which results in dilutive internal concentration polarization (ICP). On the other hand, the draw solution's concentration decreases as a result of this water displacement and results in decreased internal concentration polarization (ICP). In the forward osmosis process, the occurrence of external concentration polarization must also be considered to obtain the best operating conditions. Therefore, it is necessary to modify the equation to accommodate both types of concentration polarization. The equation is written as Equation 2 as follows:

$$
\mathrm{J}_{\mathrm{W}}=\mathrm{A}\left[\frac{\pi_{\mathrm{D}, \mathrm{b}} \exp \left(-\frac{\mathrm{JW}_{\mathrm{W}}^{\mathrm{S}}}{\mathrm{D}}\right)-\pi_{\mathrm{F}, \mathrm{b}} \exp \left(\frac{\mathrm{JW}}{\mathrm{k}}\right)}{1+\frac{\mathrm{B}}{\mathrm{JW}_{\mathrm{W}}}\left[\exp \left(\frac{\mathrm{JW}_{\mathrm{W}}}{\mathrm{K}}\right)-\exp \left(-\frac{\mathrm{JW}_{\mathrm{W}}^{\mathrm{S}}}{\mathrm{D}}\right)\right]}\right]
$$

where the $\pi_{D, b}$ value is the bulk draw solution osmotic pressure, while $\pi_{F, b}$ is the bulk feed osmotic pressure. The mass transfer coefficient is represented in $\mathrm{k}$, while the resistivity of the solute is represented in $\mathrm{K}$. The two coefficients can represent the presence of 
concentration polarization, be it ICP or ECP.

\subsection{Osmotic Pressure}

The value of osmotic pressure can be calculated through the Van't Hoff equation, which is written in Equation 3 as follows:

$$
\pi=\mathrm{nCRT}
$$

where $\mathrm{n}$ is the Van't Hoff factor, which represents the number of particles present in the solution, $\mathrm{C}$ is the solution's concentration, $\mathrm{R}$ is the ideal gas constant, and $\mathrm{T}$ is the absolute temperature. Equation 3 can be applied to a solution with a dilute concentration because, at an aqueous concentration, the characteristic of osmotic pressure applies linearly to the concentration. Thus, another approach is needed that can represent the relationship between the concentration and osmotic pressure at different concentrations. This approach is often taken by calculating the osmotic pressure as a function of water activity, which is written in Equation 4 as follows:

$$
\pi=-\left(\frac{\mathrm{RT}}{\mathrm{V}}\right) \ln \left(\mathrm{a}_{\mathrm{W}}\right)
$$

where $\mathrm{V}$ is the molar volume of water, while $\mathrm{a}_{\mathrm{W}}$ is the activity of water. The system's activity model needs to be chosen appropriately so that the osmotic pressure obtained can represent the real conditions. The Pitzer equation for electrolyte solution (Khraisheh et al., 2020) is as follows:

$$
\mathrm{a}_{\mathrm{W}}=\exp \left(-0.01802 \varnothing \sum_{\mathrm{i}} \mathrm{M}_{\mathrm{i}}\right)
$$

where $M_{i}$ is the dissolved molality and $\emptyset$ is the activity coefficient. The activity coefficient is calculated through Equation 6 as follows:

$$
\begin{gathered}
\emptyset-1=\mathrm{z}_{\mathrm{m}} \mathrm{z}_{\mathrm{x}} \mathrm{F}+2 \mathrm{~m}\left(\frac{\mathrm{v}_{\mathrm{m}} \mathrm{v}_{\mathrm{x}}}{\mathrm{v}}\right) \mathrm{B}_{\mathrm{mx}}+2 \mathrm{~m}^{2}\left[\frac{\left(\mathrm{v}_{\mathrm{m}} \mathrm{v}_{\mathrm{x}}\right)^{1.5}}{\mathrm{v}}\right] \mathrm{C}_{\mathrm{mx}} \\
\mathrm{F}=-\frac{0.3921^{0.5}}{1+1.21^{0.5}} \\
\mathrm{I}=0.5\left(\sum_{\mathrm{i}} \mathrm{m}_{\mathrm{i}} \mathrm{z}_{\mathrm{i}}^{2}\right) \\
\left|\mathrm{z}_{\mathrm{m}} \mathrm{z}_{\mathrm{x}}\right|=\frac{\sum_{\mathrm{i}} \mathrm{m}_{\mathrm{i}} \mathrm{z}_{\mathrm{i}}^{2}}{\sum_{\mathrm{i}} \mathrm{m}_{\mathrm{i}}} \\
\mathrm{B}_{\mathrm{mx}}=\mathrm{B}_{\mathrm{mx}}(0)+\mathrm{B}_{\mathrm{mx}} \exp \left(-2.01^{0.5}\right)
\end{gathered}
$$

where $z_{x}$ and $z_{m}$ are ionic charges and $\mathrm{v}_{\mathrm{x}}$ and $\mathrm{v}_{\mathrm{m}}$ are the ion's stoichiometric coefficients, while $B_{m x}(0)$ and $\mathrm{C}_{\mathrm{mx}}$ are solute-specific Pitzer constants (Pitzer, 1973).

\subsection{Mass Transfer Coefficient}

The effect of external concentration polarization (ECP) on the forward osmosis process is represented by the mass transfer coefficient $(\mathrm{k})$, while the value of this parameter can be approximated by Equation 11 as follows:

$$
k=\frac{S h D}{d_{h}}
$$

where $d_{h}$ is the hydraulic diameter of the membrane channel, Sh is the Sherwood number, and $D$ is the diffusivity coefficient (Bhinder et al., 2018). The $d_{h}$ value can be calculated using Equation 12 as follows:

$$
\mathrm{d}_{\mathrm{h}}=\frac{4 \mathrm{WH}}{\mathrm{W}+\mathrm{H}}
$$

where $\mathrm{H}$ is the height and $\mathrm{W}$ is the width of the membrane channel. The diffusivity coefficient in Equation 13 in the forward osmosis system depends on the type of species used. The existing Re value knows the type of flow present in the forward osmosis system. If the value is $\operatorname{Re}<2000$, then it is the flow of a laminar system, while the value of $\operatorname{Re}>4000$ 
means the system is turbulent; besides the two systems, there is another system, namely the transition region value of $2000<R e<4000$. The Reynolds number value can be calculated through Equation 13 as follows:

$$
\operatorname{Re}=\frac{d_{\mathrm{h}} \mathrm{v} \rho}{\mu}
$$

where $\mu$ is the dynamic viscosity, $\rho$ is the solution's density, and $v$ is the flow rate of the solution. The calculation of the Sherwood number (Sh) for a laminar flow system can be performed with Equation 14 (McCutcheon and Elimelech., 2006):

$$
\mathrm{Sh}=1.85\left(\operatorname{ReSc} \frac{\mathrm{d}_{\mathrm{h}}}{\mathrm{L}}\right)^{0.33}
$$

whereas for the turbulent flow system, it can be performed with Equation 15:

$$
\mathrm{Sh}=1.85 \mathrm{Re}^{0.75} \mathrm{Sc}^{0.33}
$$

where Re is the Reynolds number and Sc is the Schmidt number. The value of the Schmidt number can be calculated by Equation 16 as follows:

$$
\mathrm{Sc}=\frac{\mathrm{v}}{\mathrm{D}}
$$

where $\mathrm{v}$ is the kinematic viscosity.

\subsection{Solute Resistivity}

The effect of external concentration polarization (ECP) on the forward osmosis process is represented by solute resistivity, while the value of this parameter can be approximated by Equation 17 as follows:

$$
\mathrm{K}=\frac{\mathrm{t} \tau}{\mathrm{D} \varepsilon}
$$

where $t$ is the membrane thickness, $\tau$ is the membrane tortuosity, and $\varepsilon$ is the membrane porosity. The value of the three parameters $t, \tau$, and $\varepsilon$ can be represented as a membrane structural parameter $(\mathrm{S})$, whereas in this study, the values are assumed to be constant. The value can be calculated using Equation 18 as follows:

$$
\mathrm{J}_{\mathrm{W}}=\mathrm{A}\left[\frac{\pi_{\mathrm{D}, \mathrm{b}} \exp \left(-\mathrm{J}_{\mathrm{W}} \mathrm{K}\right)-\pi_{\mathrm{F}, \mathrm{b}} \exp \left(\frac{\mathrm{J}_{\mathrm{W}}}{\mathrm{k}}\right)}{1+\frac{\mathrm{B}}{\mathrm{J}_{\mathrm{W}}}\left[\exp \left(\frac{\mathrm{J}_{\mathrm{W}}}{\mathrm{k}}\right)-\exp \left(-\mathrm{J}_{\mathrm{W}} \mathrm{K}\right)\right]}\right]
$$

\section{Results and Discussion}

\subsection{Effect of $p H$ on Water Flux}

The resulting water flux determines the performance of the forward osmosis process. Therefore, research on the effect of operating conditions in the forward osmosis process needs to be performed, one of which is $\mathrm{pH}$. In this research, several $\mathrm{pH}$ variations were carried out, namely 7,6 , and 5 at $40^{\circ} \mathrm{C}$. The choice of operating temperature at $40^{\circ} \mathrm{C}$ is based on the Van't Hoff theory, which is related to increased osmotic pressure as a function of temperature; this will result in the highest water flux gain. The results obtained are presented in Figure 2a.

As the pH increases, the water flux decreases, as this is related to the isoelectric point of the membrane. Research conducted by Zhang et al. showed that $\mathrm{pH}$ has an effect on water flux during the forward osmosis process (Zhang et al., 2017). Conversely, when the pH of the solution decreases, the resulting water flux increases. The reason for this phenomenon is the presence of a positive charge in the solution, resulting in decreased mobility of the ions from the membrane surface, thus forming a concentration polarization. Similar conditions have also occurred in research related to the effect of charge on the performance 

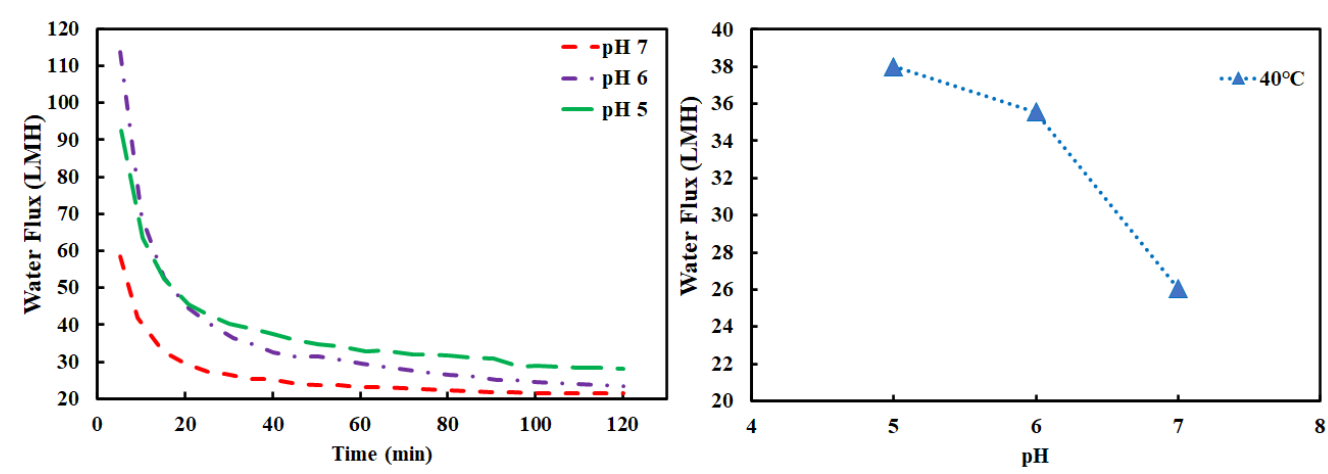

Figure 2 Water flux profile: (a) During process; (b) Average, both at $40^{\circ} \mathrm{C}$

of several types of membranes (Wadekar et al., 2017). The mean flux for these variations is presented in Figure $2 \mathrm{~b}$, supporting the previous statement that decreasing the solution's $\mathrm{pH}$ increased the water flux.

\subsection{Effect of Temperature on Water Flux}

The effect of temperature on the forward osmosis process was also investigated; this was intended to determine the importance of the forward osmosis operating temperature in obtaining the best water flux. In this study, several temperature variations were tried out, namely $40^{\circ} \mathrm{C}, 35^{\circ} \mathrm{C}$, and $30^{\circ} \mathrm{C}$; this selection was related to the membrane's maximum operating temperature, which could not be more than $50^{\circ} \mathrm{C}$. Theoretically, with increasing operating temperature, the resulting water flux will be higher, but the increase shows that the results support the existing theory. The results are presented in Figure 3a as follows.
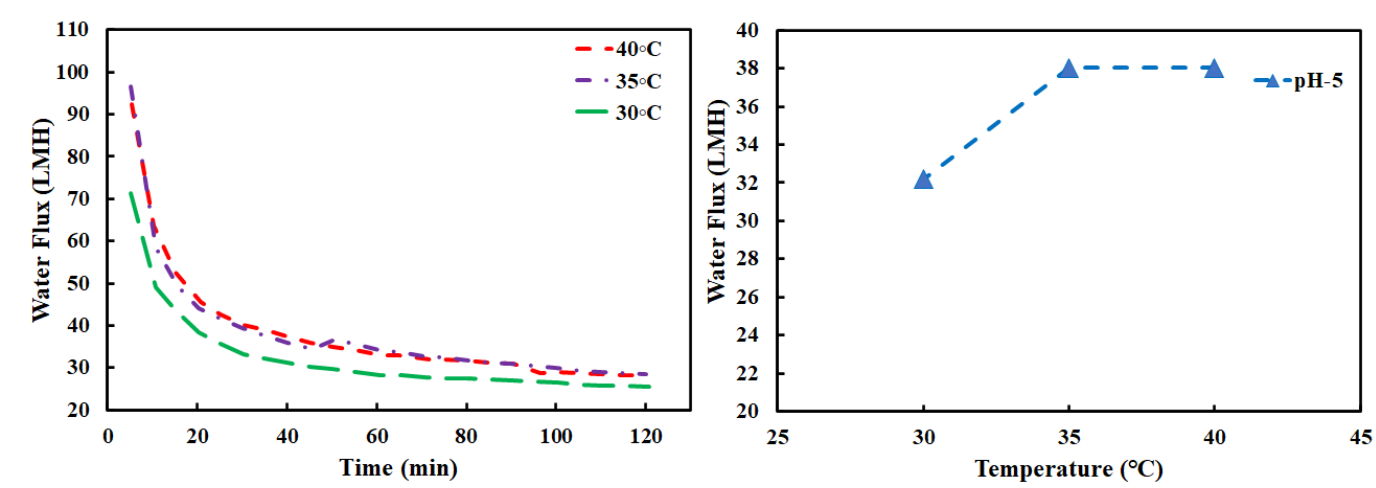

Figure 3 Water flux profile: (a) During the process; (b) Average, both at pH 5

However, Figure $3 a$ shows that the flux at $40^{\circ} \mathrm{C}$ is almost the same at $35^{\circ} \mathrm{C}$. The cause of anomalies may occur because there is also a fouling process on the membrane during the forward osmosis process. In this research, fouling was not studied, so its effect cannot be ascertained more sharply. Based on the solubility properties of chloride salts, the solution has a positive enthalpy, so an increase in temperature tends to increase the osmotic pressure, which also results in an increase in the resulting water flux (Kim et al., 2017). The mean flux produced at the temperature variations, indicating that an increase in temperature generally increases the water flux, as shown in Figure $3 \mathrm{~b}$.

\subsection{Investigation of Water Flux Models}

The water flux model's prediction in the forward osmosis (F0) process was investigated to determine the best process conditions. The proposed model considers the effect of internal concentration polarization (ICP) and external concentration polarization (ECP) and uses the ideal osmotic pressure (Van't Hoff) and real osmotic pressure (activity 
model) approach. The activity model used is that of Pitzer, adapted from the research of Khraisheh et al. (2020). The increase in temperature during the forward osmosis process is also related to the ICP and ECP phenomena; the increase in process temperature results in an increase in the diffusivity of the dissolved compound, which also results in an increase in the mass transfer coefficient $(\mathrm{k})$ and ends with a decrease in ECP. The increase in solvent diffusivity affects the ICP value decreases due to a decreased solute resistivity (K) value (Ghiu et al., 2002).

This research was first carried out by investigating the values of parameters $A$ and $B$, as for the obtained values obtained by $0.027 \mathrm{~m} / \mathrm{atm} . \mathrm{d}$ and $2.8 \times 10^{-4} \mathrm{~m} / \mathrm{d}$ (McCutcheon et al., 2006). The investigation procedure was carried out by calculating the increase in the average conductivity of deionized water as feed for the forward osmosis process, using $1 \mathrm{M}$ $\mathrm{NaCl}$ as the draw solution (Yip et al., 2010). The structural parameter (S) was determined using calculations to determine how much influence the membrane structure has on solute resistivity. The results showed that the structural parameters' value for the ideal osmotic pressure approximation is around $2.58 \times 10^{-5}$, while the osmotic pressure approach uses water activity at around $2.35 \times 10^{-5}$.

The values of the osmotic pressure and mass transfer coefficient are strongly influenced by the temperature. Apart from being influenced by temperature, the value of the external polarization concentration can be manipulated by increasing the system's flow rate. In this case, temperature plays a role in density, viscosity, and diffusivity (McCutcheon and Elimelech, 2006). The simulation results show that the model can describe the phenomena that occur during the process, while in this case, it is expressed as water flux, presented in Figure 4, as follows:
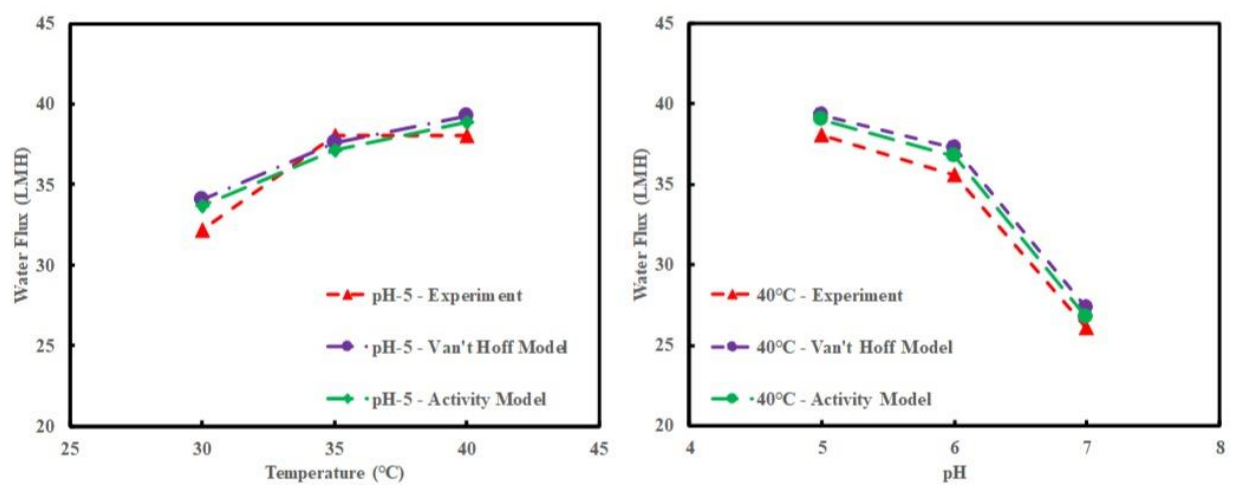

Figure 4 Water flux model: (a) At $40^{\circ} \mathrm{C}$; (b) At pH 5

The two water flux modeling results show that the activity model is better than the Van't Hoff model in predicting the phenomena that occur. The limitation of the Van't Hoff model is the linearity of the osmotic pressure as a function of concentration; this is not suitable for concentrated solutions because the ideal properties of the solution only apply to dilute solutions. As a comparison, research has been carried out on sodium chloride $(\mathrm{NaCl})$ solution at various concentrations (with a constant temperature of $25^{\circ} \mathrm{C}$ ), so the bond between osmotic pressure is obtained as a function of concentration; this is presented in Figure 5a. It can be seen that the linearity of the osmotic pressure as a function of concentration is limited to $2 \mathrm{M}$ concentrations (Khraisheh et al., 2020). The value of the water flux rate that can be moved from the feed liquid body to the draw solution largely determines the lithium recovery performance. When compared with other lithium recovery processes, such as conventional evaporation (CE) and nanofiltration (NF), which have an average flux yield of $0.37-0.55$ and $22.5 \mathrm{~kg} \mathrm{~m}^{-2} \mathrm{~h}^{-1}$ (Park et al., 2020), forward osmosis (FO) 
can be said to have higher potential. The average between methods is compared in Figure $5 b$.
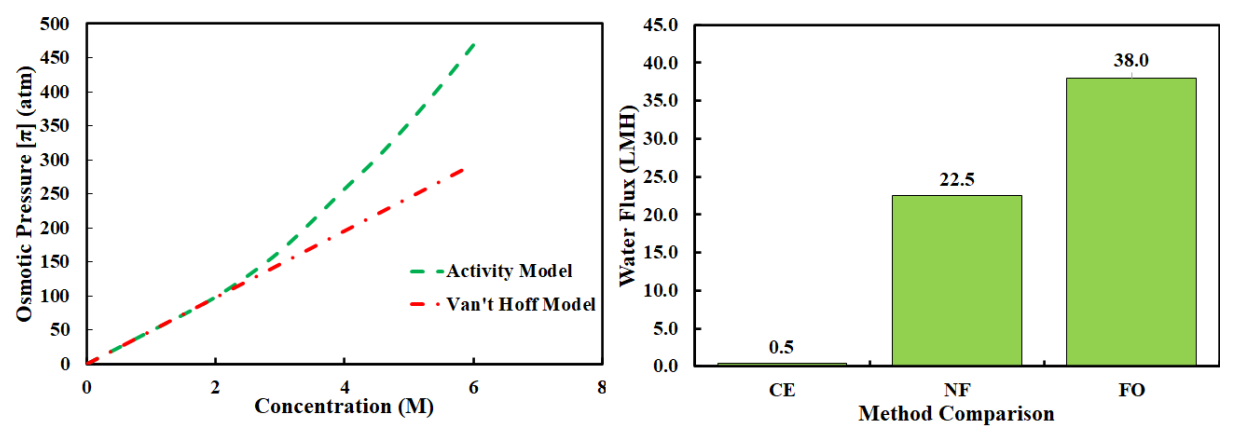

Figure 5 (a) Osmotic pressure model; (b) Water flux of various lithium recovery processes

The best operating conditions for the conventional evaporation (CE) process take place in a laboratory where the conditions are compared to the actual environment, while the nanofiltration (NF) process takes place at an operating pressure of 10 bar (Park et al., 2020). The potential osmotic pressure of the draw solution at a concentration of $6 \mathrm{M}$ is around $450 \mathrm{~atm}$, which is why the forward osmosis (FO) process is better than CE and NF (as can be seen in Figure 5a).

\subsection{Lithium Recovery Investigations}

The potential of forward osmosis (FO) for the lithium recovery process is realized by comparing the initial concentration of the process and the concentration rate until the end of the process. The expression is carried out in a concentration ratio of the beginning and the end of the process. The ratio of the results of this research is presented in Figure 6 as follows:
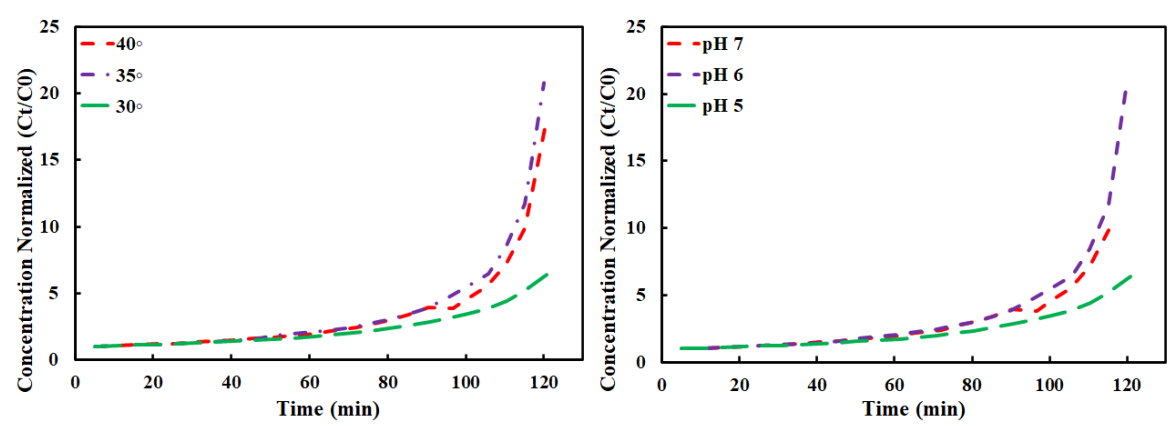

Figure 6 Normalized concentration ratio: (a) At pH 5; (b) At $40^{\circ} \mathrm{C}$

The results of the comparison of temperature variations showed that the highest lithium concentration ratio was at $35^{\circ} \mathrm{C}$ with a value of 20.5 , while the lowest was at $30^{\circ} \mathrm{C}$ with 6.3, which is presented in Figure 6a. Under operating conditions of $40^{\circ} \mathrm{C}, \mathrm{pH}$ variations were carried out to obtain a comparison of the results presented in Figure 6b. Theoretically, the FO process has no selectivity towards ion transfer and is able to reject ions efficiently. The results of research conducted by Li et al., who studied the enrichment of lithium from seawater, yielded a lithium rejection range of $80-93 \%$ (Li et al., 2018). The results presented in Figure 6 show that lithium concentrations can be up to 20 times under the best conditions. The results show the potential for the forward osmosis process to be developed for a pilot scale before being implemented in the industrial sector. However, it is necessary to develop further methods for concentrating the draw solution. 


\section{Conclusions}

The research results generally show that a temperature increase in the forward osmosis process results in an increase in water flux. This condition is related to the influence of temperature on density, viscosity, diffusivity, and others. Conversely, an increase in $\mathrm{pH}$ in the forward osmosis process tends to decrease the water flux; this is related to the charged membrane's property, resulting in a tendency to better separation. Meanwhile, the comparison between experiments and modeling shows that the ICP and ECP phenomena's occurrence plays a major role during the forward osmosis process. The best conditions of the research were obtained at a variation of $\mathrm{pH} 5$ with a process temperature of $40^{\circ} \mathrm{C}$, and the ratio of normalized concentrations reached 20 times the initial concentration. This potential is also evidenced by the high water flux value in the lithium recovery process using an FO of around $38 \mathrm{LMH}$. Further research will include the effect of the ratio of lithium in the feed solution, the effect of the concentration of the draw solution, and the pilot scale model.

\section{Acknowledgements}

The authors are grateful for the support of Gadjah Mada University and the collaboration of the Research and Development Division for Mineral Technology Lampung, National Research and Innovation Agency (BRIN) for the laboratory facilities used in the research. Highly appreciation is also delivered to the Ministry of Higher Education for the financial support to conduct this research.

\begin{tabular}{|ll|}
\hline Nomenclature & Water flux \\
$\mathrm{J}_{\mathrm{W}}$ & Water permeability coefficient \\
$\mathrm{A}$ & Solute permeability coefficient \\
$\mathrm{B}$ & Osmotic Pressure of draw solution \\
$\pi_{\mathrm{D}}$ & Osmotic Pressure of feed solution \\
$\pi_{\mathrm{F}}$ & Osmotic pressure of the bulk draw solution \\
$\pi_{\mathrm{D}, \mathrm{b}}$ & Osmotic pressure of the bulk feed solution \\
$\pi_{\mathrm{F}, \mathrm{b}}$ & Membrane structural parameter \\
$\mathrm{S}$ & Salt diffusion coefficient \\
$\mathrm{D}$ & Resistance to salt transport in the porous support \\
$\mathrm{K}$ & Osmotic pressure \\
$\pi$ & Ideal gas constant \\
$\mathrm{R}$ & Concentration \\
$\mathrm{C}$ & Water molar volume \\
$\mathrm{V}$ & Water activity \\
$\mathrm{a}_{\mathrm{W}}$ & Molality \\
$\mathrm{M}$ & Activity coefficient \\
$\varnothing$ & Ionic charges \\
$z_{x}$ and $z_{m}$ & Solute-specific Pitzer constants \\
$B_{m x}(0)$ and $\mathrm{C}_{\mathrm{mx}}$ & Mass transfer coefficient \\
$\mathrm{k}$ & Hydraulic diameter of the membrane channel \\
$\mathrm{d}_{\mathrm{h}}$ & Sherwood number \\
$\mathrm{Sh}$ & Reynolds number \\
$\mathrm{Re}$ & Flow rate of the solution \\
$\mathrm{v}$ & Density of the solution \\
$\rho$ & Schmidt number \\
$\mathrm{Sc}$ & Width of the membrane channel \\
$\mathrm{W}$ & Height of the membrane channel \\
$\mathrm{H}$ & Dynamic viscosity \\
$\mu$ & Membrane thickness \\
$\mathrm{t}$ & Membrane tortuosity \\
$\tau$ & Membrane porosity \\
$\varepsilon$ & Kinematic viscosity \\
$v$ & Reverse osmosis \\
$\mathrm{RO}$ & \\
& \\
\hline
\end{tabular}




\begin{tabular}{|ll|}
\hline FO & Forward osmosis \\
CTA & Cellulose Triacetate \\
ICP & Internal concentration polarization \\
ECP & External concentration polarization \\
\hline
\end{tabular}

\section{References}

Awad, A.M., Jalab, R., Minier-Matar, J., Adham, S., Nasser, M.S., Judd, S.J., 2019. The Status of Forward Osmosis Technology Implementation. Desalination, Volume 461, pp. 10-21

Bhinder, A., Shabani, S., Sadrzadeh, M., 2018. Effect of Internal and External Concentration Polarizations on the Performance of Forward Osmosis Process. Osmotically Driven Membrane Processes - Approach, Development and Current Status. IntechOpen

Cath, T.Y., Childress, A.E., Elimelech, M., 2006. Forward Osmosis: Principles, Applications, and Recent Developments. Journal of Membrane Science, Volume 281(1-2), pp. 70-87

Desiriani, R., Kresnowati, M.T.A., Wenten, I., 2017. Membrane-Based Downstream Processing of Microbial Xylitol Production. International Journal of Technology, Volume 8(8), pp. 1393-1401

Flexer, V., Baspineiro, C.F., Galli, C.I., 2018. Lithium Recovery from Brines: A Vital Raw Material for Green Energies with a Potential Environmental Impact in its Mining and Processing. Science of the Total Environment, Volume 639, pp. 1188-1204

Ghiu, S.S., Carnahan, R., Barger, M., 2002. Permeability of Electrolytes Through a Flat R0 Membrane in a Direct Osmosis Study. Desalination, Volume 144(1-3), pp. 387-392

Gruber, P.W., Medina, P.A., Keoleian, G.A., Kesler, S.E., Everson, M.P., Wallington, T. J., 2011. Global Lithium Availability: A Constraint for Electric Vehicles? Journal of Industrial Ecology, Volume 15(5), pp. 760-775

Hamzaoui, A.H., M'nif, A., Hammi, H., Rokbani, R., 2003. Contribution to the Lithium Recovery from Brine. Desalination, Volume 158(1-3), pp. 221-224

Holloway, R.W., Childress, A.E., Dennett, K.E., Cath, T.Y., 2007. Forward Osmosis for Concentration of Anaerobic Digester Centrate. Water Research, Volume 41(17), pp. 4005-4014. https://doi.org/10.1016/j.watres.2007.05.054

Khraisheh, M., Dawas, N., Nasser, M.S., Al-Marri, M.J., Hussien, M.A., Adham, S., McKay, G., 2020. Osmotic Pressure Estimation using the Pitzer Equation for Forward Osmosis Modelling. Environmental Technology, Volume 41(19), pp. 2533-2545

Kim, S.J., Kook, S., O’Rourke, B.E., Lee, J., Hwang, M., Kobayashi, Y., Suzuki, R., Kim, I. S., 2017. Characterization of Pore Size Distribution (PSD) in Cellulose Triacetate (CTA) and Polyamide (PA) Thin Active Layers by Positron Annihilation Lifetime Spectroscopy (PALS) and Fractional Rejection (FR) Method. Journal of Membrane Science, Volume 527(June 2016), pp. 143-151

Li, L., Deshmane, V.G., Paranthaman, M.P., Bhave, R., Moyer, B.A., Harrison, S., 2018. Lithium Recovery from Aqueous Resources and Batteries: A Brief Review. Johnson Matthey Technology Review, Volume 62(2), pp. 161-176

Martin, G., Rentsch, L., Höck, M., Bertau, M., 2017. Lithium Market Research - Global Supply, Future Demand and Price Development. Energy Storage Materials, Volume 6, pp. 171179

McCutcheon, J.R., Elimelech, M., 2006. Influence of Concentrative and Dilutive Internal Concentration Polarization on Flux Behavior in Forward Osmosis. Journal of Membrane Science, Volume 284, pp. 237-247

McCutcheon, J.R., McGinnis, R.L., Elimelech, M., 2006. Desalination by Ammonia-Carbon Dioxide Forward Osmosis: Influence of Draw and Feed Solution Concentrations on Process Performance. Journal of Membrane Science, Volume 278(1-2), pp. 114-123

McGinnis, R.L., Elimelech, M., 2007. Energy Requirements of Ammonia-Carbon Dioxide 
Forward Osmosis Desalination. Desalination, Volume 207(1-3), pp. 370-382

Monjezi, A.A., Mahood, H.B., Campbell, A.N., 2017. Regeneration of Dimethyl Ether as a Draw

Solute in Forward Osmosis by Utilising Thermal Energy from a Solar Pond.

Desalination, Volume 415, pp. 104-114

Naumov, A.V., Naumova, M.A., 2010. Modern State of the World Lithium Market. Russian Journal of Non-Ferrous Metals, Volume 51(4), pp. 324-330

Park, S.H., Kim, J.H., Moon, S.J., Jung, J.T., Wang, H.H., Ali, A., Quist-Jensen, C.A., Macedonia, F.,

Drioli, E., Lee, Y.M., 2020. Lithium Recovery from Artificial Brine using Energy-Efficient Membrane Distillation and Nanofiltration. Journal of Membrane Science, Volume 598, https://doi.org/10.1016/j.memsci.2019.117683

Pitzer, K.S., 1973. Thermodynamics of Electrolytes. I. Theoretical Basis and General Equations. Journal of Physical Chemistry, Volume 77(2), pp. 268-277

Setiawan, F.A., Rahayuningsih, E., Petrus, H.T.B.M., Nurpratama, M.I., Perdana, I., 2019. Kinetics of Silica Precipitation in Geothermal Brine with Seeds Addition: Minimizing Silica Scaling in a Cold Re-Injection System. Geothermal Energy, Volume 7(1), pp. 1-16 Suprapto, S., Gotoh, T., Humaidah, N., Febryanita, R., Firdaus, M.S.i., Ningrum, E.O., 2020. The Effect of Synthesis Condition of the Ability of Swelling, Adsorption, and Desorption of Zwitterionic Sulfobetaine-based Gel. International Journal of Technology, Volume 11(2), pp. 299-309

Swain, B., 2017. Recovery and Recycling of Lithium: A Review. Separation and Purification Technology, Volume 172, pp. 388-403

Utami, T.S., Arbianti, R., Manaf, B.N., 2015. Sea Water Desalination using Debaryomyces Hansenii with Microbial Desalination Cell Technology. International Journal of Technology, Volume 6(7), pp. 1094-1100

Wadekar, S.S., Vadic, R.D., 2017. Influence of Active Layer on Separation Potentials of Nanofiltration Membranes for Inorganic Ions. Environmental Science and Technology, Volume 51, pp. 5658-5665

Wang, W., Zhang, Y., Esparra-Alvarado, M., Wang, X., Yang, H., Xie, Y., 2014. Effects of pH and Temperature on Forward Osmosis Membrane Flux using Rainwater as the Makeup for Cooling Water Dilution. Desalination, Volume 351, pp. 70-76

Yip, N.Y., Tiraferri, A., Phillip, W.A., Schiffman, J.D., Elimelech, M., 2010. High Performance Thin-film Composite Forward Osmosis Membrane. Environmental Science \& Technology, Volume 44(10), pp. 3812-3818

Zhang, X., Li, Q., Wang, J., Li, J., Zhao, C., Hou, D., 2017. Effects of Feed Solution pH and Draw Solution Concentration on the Performance of Phenolic Compounds Removal in Forward Osmosis Process. Journal of Environmental Chemical Engineering, Volume 5(3), pp. 2508-2514 